\title{
Determinants of Flood Disaster Households' Vulnerability in Nepal
}

\author{
Raghu Bir Bista, PhD \\ Assistant Professor of Economics, Patan Multiple Campus, Tribhuvan University, Nepal \\ Email: bistanepal@gmail.com
}

\begin{abstract}
Almost all extreme socio economic vulnerabilities relate to natural disasters and its economic loss at household level, along with socio economic characteristics of household. This relationship creates great curiosity estimating determinants and levels of vulnerability at micro level for policy understanding for minimizing household vulnerability. This paper measures empirically the determinants of vulnerability of natural disasters at household level based on primary data sets collected from household survey in Sot Khola water basin by using multiple econometric models. The descriptive analysis shows a huge loss with a worth 13,344,000 Rupees including crops, assets and physical infrastructure. Despite its small worth, life was worst due to loss of house, crops, clean drinking water, electricity, documents, foods, communication, displacement etc. Furthermore, the result of the model shows rural orthodox society having indigenous knowledge and skill, conservative agrarian family, traditional labor force, primitive technology etc. Loss and income of household have positive relationship but labor, early warning and knowledge of disasters have negative relationship. Knowledge of disasters have made household resilient to reduce economic loss and then household vulnerability. Households in the geography of Gadhi and Lekhagaon are more resilient than of Kunathari. Therefore, climate resilience is urgent issue to minimize household vulnerability for household income and welfare.
\end{abstract}

Key words: natural disasters, vulnerability, income, poverty, climate resilience Nepal

JEL Classification : Q 25, Q 32, Q 56, Q 57, P 281

\section{INTRODUCTION}

Vulnerability is a wider and deepening spreading issue in the world. World Bank (2016) calculates $\$ 520$ billion economic loss of natural disasters in annual consumption and enforces about 26 million people into poverty per year. In another words, disasters produce a large vulnerable population all over the world. In addition, the vulnerable population heavily pays more than non-vulnerable population in the study of 117 countries because the poor people have a limited ability to cope with natural disasters. It is 60 percent costs in annual consumption. In Bangladesh, disasters facts reveal 219 natural disasters destroying \$ 16 billion loss and millions of homes, devastated livelihoods and led to the spread of disease (IEDRO, 2010). 
In 2004, floods on the Ganges, Brahmaputra, Jamuna, and Meghna affected 30 million people and submerged $40 \%$ of Bangladesh's capital, Dhaka. In 2009, tropical Cyclone Alia forced the evacuation of half a million people, damaged or destroyed half a million houses, and destroyed hundreds of thousands of acres of cropland. Worst, however, was the 1970 Bhola cyclone. Estimates put the death toll at 500,000 people, making it the deadliest tropical storm in recorded history (IEDRO, 2010). Similarly, more than 80 percent of the total population of Nepal is at risk of natural hazards such as floods, landslides, windstorms, hailstorms, fires, earthquakes and Glacial Lake Outburst Floods (GLOFs) (MoH, 2017). Thus, vulnerability is a central issue of social sciences and development economics.

A large number of social scientists and economics scholars have recently focused on vulnerability to natural disasters and climate change to find out alternative policy measures for building resilient development and community for reducing vulnerable population in the world. A group of literatures has conceptualized vulnerability to be understood in depth. It is understood as helpless socio economic and political human condition leads to exposure to natural disasters more than other higher socio economic human condition. Extensive research over the past 30 years has revealed that it is generally the poor who tend to suffer worst from disasters (Twigg, 2004; Wisner et al., 2004; UNISDR, 2009b). In simple, it can be explained as the poor section of people. Wisner et al (2004) has similar argument that vulnerability is not simply about poverty, but Poverty is both a driver and consequence of disaster risk (particularly in countries with weak risk governance) because economic pressures force people to live in unsafe locations (see exposure) and conditions. Twigg (2004) explains it as human dimension of disasters and as the result of economic, social, cultural, institutional, political and psychological factors that shape people's lives and the environment that they live in. Thus, we can draw it as the people having 'fragility', 'weakness', 'deficiency' or 'lack of capacity'. In another words, it is "susceptibility to harm" or "exposure to natural hazards".

Similarly, on vulnerability, Birkmann, (2006) explains its concerns the wider environmental and social conditions that limit people and communities to cope with the impact of hazard. These processes produce a range of immediate unsafe conditions such as living in dangerous locations or in poor housing, ill-health, political tensions or a lack of local institutions or preparedness measures. IPCC (2012) elaborates its determinants by historical, political, cultural and institutional and natural resource processes that shape the social and environmental conditions people find themselves existing within. 
Vulnerability is a set of conditions that negatively affect the ability of people to prepare for and withstand disaster (Warmington, 1995; Lewis 1997, 1999; Alexander, 2000; Clark, Cash, Corell, Dickson, Hall \& Parson, 2000; UNDP, 2004). Turner II et al. (2003) mentions it as the inability to withstand the effects of a hostile environment. Hodinott and Quisumbing (2003) provided socio economic dimension of vulnerability in which the study used household data for quantification of risk and vulnerability for focusing three dimensions: expected poverty, expected low utility and uninsured exposure to risk. In simple, it is the capacity to be wounded, i.e. the degree to which a system is prospectively to feel harm in the exposure to a hazard. It has different variables, relationship and perceptions of the people, although it is itself a complex, its dynamic nature and its multi-dimension (Birkmann, 2007). Similarly, Cardonna (2003) explain it to refer to risk or to define disadvantaged conditions by explaining the relationship between shock and vulnerability towards risk. Chambers (1989) mentions external side (risks, shocks and stress to individual) and internal side (defenseless of individual (physically weaker, economically improvised, socially dependent and psychologically humiliated)-no means to cope without damaging loss). Differently but similarly, Watts and Bohles(1993) argue like as Chambers (1989), Blaikie, 1994, Varley,1994, Bolin and Stanford, 1998, Brooks 2003 and Adger, Brooks, Bentham, Agnew and Eriksen, 2004, Blaikie, Cannon, Davis and Wisner (1994). Differently, Adger (2000) and Adger (2006) argue it in terms of exposure and susceptibility to and harm by social and environmental stress, and can be associated with the capacity to cope with the impending or existing disaster. Similarly, the United Nations Environment Program (UNEP) (2003) argues it as shock's consequences including loss of human lives, malnutrition, income losses, water stress, and environmental degradation. On this issue, theoretical and empirical literatures have gradually captured to analyze how much socio economic variables affect to natural disasters induced household vulnerability to understand which types of policy shock is required to minimize such vulnerability.

In Nepal, none literatures have covered on the relationship between vulnerability and natural disasters and socio economic determinants of household vulnerability. Therefore, this study is urgent need to contribute valuable policy inputs and to fill up such gap for policy measures in pre and post disasters for building resilient individual household and community for coping adverse effects of natural disasters. This study is to estimate the effects of socio economic variables on household vulnerability in Nepal focusing specifically to assess on natural shock and household vulnerability level, to identify socio economic characteristics of households and to assess their effects on household vulnerability in Nepal.

Above objective is answered based on UNDP's Household Survey 2015 in Sotkhola watershed areas by using vulnerability concept framework. Therefore, the study needs 
information about socio economic determinants information and natural disasters because socio economic variables represent adaptation capacity of household to resist natural disasters as well as to minimize its adverse effects on the community. If socio economic variables are strong, vulnerability will be lower, despite strong natural disasters. If not, vulnerability will be extremely higher. Thus, the level of defenseless determines household vulnerability.

\section{MATERIALS AND METHOD}

To understand how socio economic variables affecting household vulnerability level during natural shocks in Nepal, UNDP's household survey is undertaken in the Sotkhola water basin and its catchment areas (Figure 1) in the northern part of Surkhet, the western Nepal. The water basin is a tributary of a big river, Bheri (Figure 1). Its length is about $30 \mathrm{~km}$ originated from Chandane, Gadhi VDC and ends to Rakseni, Kunathari VDC (Figure 1)(DDC, 2015). Its water level seems to be permanent character but its fluctuation occurs in the different seasons from monsoon to winter. In winter, its water level is unexpectedly lower. Thus, the river is a monsoon lover.

Geomorphological of the water basin has mainly three catchment areas having 28 square spread from sea level to Mahabharata range: Gadhi VDC (Upper stream), Lekhagaon VDC (middle stream) and Kunathari VDC (downstream) (DDC, 2015). Such hilly and mountainous landscape is rich for heterogeneity and diversity in wildlife and ecosystem. Demographically, population size is about 3369, out of which main castes are Magar (37.7 percent), Brahmin (30.6 percent), Cheetri (17.1 percent), Sunwar (5.7 percent) and others (22.6 percent). Others include Kami, Sarki, Thakuri, Gurung, Damai, Sherpa among others (VDC, 2015). b) Lekhgaon village spreads $110 \mathrm{~km}$ length and $30 \mathrm{~km}$ breadth of 2451 square $\mathrm{km}$ (249016 hectare) from 198 meter (Tata pani) to 2369-meter (Matelagurase) altitude (Figure 1). Hill with 84 percent dominates to 16 percent valley. Population size is 3999 (651 households) (DDC, 2015). c) Kunathari is another study village lying between 600 meter and 1200 meter (Figure 1). It is $20 \mathrm{~km}$ far from district headquarter). Population size is 3413 (CBS, 1991) and (DDC, 2015). This water basin is a source of clean drinking water, irrigation water and water and terrestrial ecosystems to the catchment households. This study area is purposively selected by i) its climatic variation and disasters event as flooding and landslides in 2014 , ii) its huge vulnerability at the catchment areas, iii) its morphological structural change, iv) its aquatic and terrestrial ecosystem and biodiversity and v) its agricultural lifeline and its risk. 
In the study area, socio Figure 1: Sotkhola and its catchment study Area economic information, household vulnerability and natural disasters are essentials. Secondary data relates to natural disasters and household vulnerability is collected from District Development Committee (DDC) office as well as from Ministry of Home. Primary data relates to household socio economic information are collected from UNDP's Household

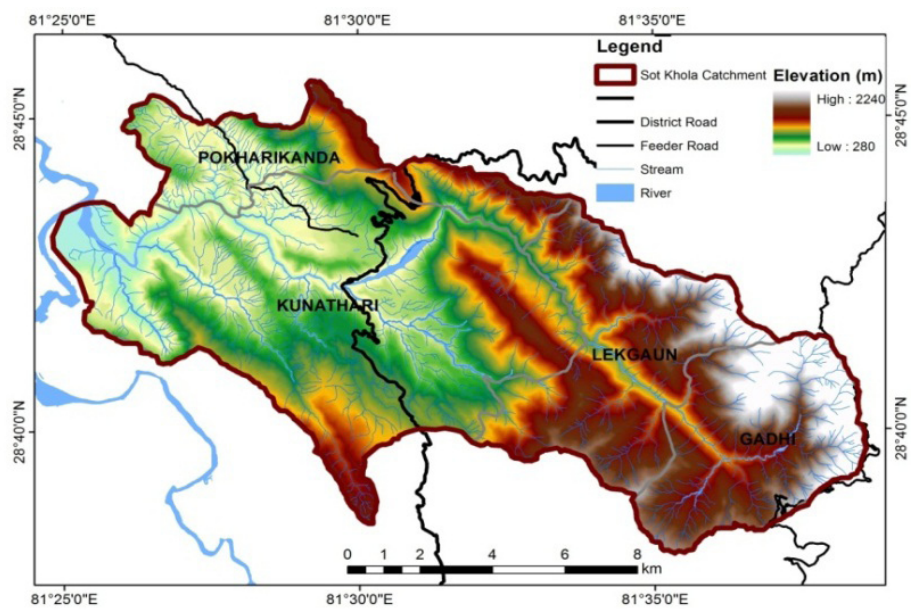

Source: GIS map of Study area based on field survey, 2015 Survey conducted in the post natural disasters in 2014 during from September 2015 to October 2015 to collect reliable and accurate data and information about climatic events and disasters and its vulnerability to install hydrological monitoring system, alert system, infrastructure and building adaptation capacity.

Data methods are household survey, focused group discussion (FGD) and key informant interview (KII). In household survey, two stage sampling method is used by using cluster sampling method covering 3310 households over all 3 rural catchment villages (Gadhi, Lekhagaon and Kunathari) in Sot khola river water basin of the western Nepal and nine clusters based on altitude, location and place. In the second stage, random sampling method to select 642 sample households (19.3\%) from out of such nine clusters is used. After then, structural questionnaire is its tool to collect about socio economic information about household (land holding, income level, source of income, size of family, gender, age, caste etc.), climatic events and vulnerability, agriculture activity and adaptation capacity, behavior and decisions in wheat production. Similarly, climatic events and vulnerability set of questionnaire provides information, experience and perspective about climatic events, its types, natures, patterns and vulnerability level. Agricultural activity related data include data related to agriculture activity, farm revenue, types of crops, crop cycle, inputs, infrastructure and markets. Lastly, adaptation capacity, behavior and decisions set provides data set related to income, information, technology, experience, indigenous skills, application and loss reduction. Further, the effects of disasters on household income loss are analyzed and identified by using semi log econometric model. 


\section{Analytical Framework}

Numerous theoretical and empirical literatures (Shen et al., 2011) on vulnerability mentions income loss of household as measurement of vulnerability. This paper follows similar analytical framework in different variables (socio economic and natural shocks) in different country, Nepal because of its relevancy. Scientifically, vulnerability depends on socio economic condition of households and natural shocks. If households have a better socio economic condition, they will have less vulnerability, despite homogeneity in their exposure to natural disasters. If not, vulnerability will be more at poor socio economic condition. Therefore, vulnerability and socio economic condition have inverse relationship and vulnerability and natural disasters have positive relationships. Its theoretical function is an equation (i) below.

$\mathrm{Y}_{\mathrm{Til}}=\mathrm{f}\left(\mathrm{X}_{\mathrm{h}^{\prime}} \mathrm{C}, \varepsilon\right)$

Where

$\mathrm{Y}_{\mathrm{Til}}=$ household's total income loss,

$\mathrm{X}_{\mathrm{h}}=$ socio economic bundle (income, literacy, asset, family size, land holding etc),

$\mathrm{C}=$ climate shock (flood, cyclone, landslide)

$\varepsilon=$ error term

\section{Econometric Models}

Income lost due to natural disaster of nth samplehouseholds refers to household vulnerability, which is influenced by heterogeneous socio economic variables (the proportion of agricultural labor, type of house, the proportion of agricultural income, member of organization, early warning, knowledge of disaster and locations( Gadhi, Lekhagaon and Kunathari)). Individual households have minimization decision and behavior to minimize the adverse effects of natural disaster. Such influence to decision and behavior depends on socio economic characteristics. Therefore, its model is

$\mathrm{Y}_{\mathrm{Til}}=\alpha+\beta\left(\mathrm{X}_{\mathrm{h}}\right),+\mu \mathrm{C}+\varepsilon$

The equation (ii) is expansionary the semi log econometric model includes nine variables (equation iii). In this model, log form income loss of household ( $\ln \mathrm{Y}_{\mathrm{TIL}}$ ) is dependent variable. Similarly, the proportion of agricultural labor $\left(\mathrm{X}_{\text {lagl }}\right)$, type of house $\left(\mathrm{X}_{2 \mathrm{th}}\right)$, the proportion of agricultural income $\left(\ln \mathrm{X}_{\mathrm{agli}}\right), \mathrm{D}_{0 \mathrm{~m}}$ (member of organization), $\mathrm{D}_{\text {lew }}$ (Early warning), $\mathrm{D}_{2 \mathrm{kd}}$ (knowledge of disaster), $\mathrm{D}_{3 \mathrm{G}}(\mathrm{Gadhi}), \mathrm{D}_{4 \mathrm{~L}}$ (Lekhagaon), and $\mathrm{D}_{5 \mathrm{~K}}$ (Kunathari) are independent variables where $\mathrm{D}_{0 \mathrm{~m}}$ (member of organization), $\mathrm{D}_{\text {lew }}$ (early warning), $\mathrm{D}_{2 \mathrm{kd}}$ (knowledge of disaster), $\mathrm{D}_{3 \mathrm{G}}$ (Gadhi), and $\mathrm{D}_{4 \mathrm{~L}}$ (Lekhagaon) are 
dummies. There are eight estimators: $\beta, \beta_{1^{\prime}} \beta_{2^{\prime}} \beta_{3^{\prime}} \beta_{4^{\prime}} \beta_{5^{\prime}} \beta_{6^{\prime}} \beta_{7^{\prime}}$ and $\beta_{8^{\prime}}$. Based on above theoretical equation (i), semi log econometric model (equation ii) is built as follows:

$\mathrm{LnY}_{\mathrm{TIL}}=\beta+\beta_{1} \operatorname{Ln} X_{\text {lagl }}+\beta_{2} \mathrm{X}_{2 \mathrm{th}}+\beta_{3} \ln \mathrm{X}_{\text {agli }}+\beta_{4} \mathrm{D}_{0 \mathrm{~m}}+\beta_{5} \mathrm{D}_{1 \mathrm{ew}}+\beta_{6} \mathrm{D}_{2 \mathrm{kd}}+\beta_{7} \mathrm{D}_{3 \mathrm{G}}+\beta_{8} \mathrm{D}_{4 \mathrm{~L}}+\varepsilon$

\section{Model Hypothesis}

Indigenous and exogenous variables have influence on household vulnerability. In this study, the proportion of household income that was lost due to climate shock induced flood was used as an indicator of household vulnerability. The household vulnerability was influenced by different socio economic variables (family member, landholding, knowledge and experience, member of organization, help, and house type, number of labor, agricultural income and geographical areas) and geographical areas. This study to construct an econometric model has the following hypothesis below.

- The proportion of household labor has an inverse relationship with household vulnerability. Its basic argument is that large or additional labor means additional physical and mental resources having capacity to earn wage income or to mobilize property and asset at the safe place. Naturally, household vulnerability will be lower.

- House if is strong and permanent; house is able to save human being, asset and financial resource from the damage of flood. Thus, the strong and permanent houses are inversely related with household vulnerability.

- The proportion of agricultural income has positive relationship with household vulnerability. If the proportion of agricultural income increases, income loss will increase and then household vulnerability will increase. Therefore, the proportion of agricultural income and household vulnerability is supposed to be positive.

- Knowledge and experience about climate shock and flood makes household capable to use effectively and efficiently skills and technology in the course of adaptation activity against the flood. Thus, it reduces household vulnerability. Therefore, knowledge and experience have inverse relationship with household vulnerability.

- The society has different community organizations working social and economic activity. As per an objective of family, household takes their membership for accessing financial and physical support. When household is in disaster or the community is in disaster, such organization will support financially and physically to reduce vulnerability by promoting adaptive activity. Therefore, their membership and their help have inverse relationship with household vulnerability. 
- Early warning makes household their preparedness and alertness. It provides time to household to reach decision to move at safe place. In this way, household vulnerability will fall down. Therefore, the early warning system has inverse relationship with household vulnerability.

- Geography has different characters such as topography and elevation influencing the vulnerability and adaptive capacity of household. Therefore, different geography has the different level of household vulnerability.

\section{Estimates of Vulnerability Coefficients}

To understand how independent socio economic variable influencing household vulnerability dependent variable, this study focus on the following two questions:

- how adaptive capacity of household influenced on household vulnerability in different geographical areas and

- what are coefficient values of independent variables. Above semi log econometric model was used for the estimation of parameters of the model.

Cross sectional data of Gadhi, Lekhagaon and Kunathari in 2015 are used to answer quantitatively above two questions from the model after the estimations of coefficients $-\beta, \beta_{1^{\prime}} \beta_{2^{\prime}} \beta_{3^{\prime}} \beta_{4^{\prime}} \beta_{5^{\prime}} \beta_{6^{\prime}}, \beta_{7^{\prime}} \beta_{8^{\prime}}$ and $\beta_{9}$ of independent variables. We could interpret the effect of above independent variables on the vulnerability of household.

\section{RESULTS}

\section{Descriptive Statistics}

Table 1 presents mean and standard deviation of key variables resulted fromthe model. In column 1 , there are 8 variables in which household vulnerability in terms of income loss of household $\left(\ln \mathrm{Y}_{\mathrm{TIL}}\right)$ is dependent variable and the proportion of agricultural labor $\left(X_{1 \text { agl }}\right)$, type of house $\left(X_{2 \text { th }}\right)$, the proportion of agricultural income $\left(\ln X_{\text {agli }}\right)$, $D_{\text {lew }}$ (early warning), $\mathrm{D}_{2 \mathrm{kd}}$ (knowledge of disaster), $\mathrm{D}_{3 \mathrm{G}}$ (Gadhi), $\mathrm{D}_{4 \mathrm{~L}}$ (Lekhagaon), and $\mathrm{D}_{5 \mathrm{~K}}$ (Kunathari) are independent variables, where $\mathrm{D}_{1 \mathrm{ew}}$ (early warning), $\mathrm{D}_{2 \mathrm{kd}}$ (knowledge of disaster), $\mathrm{D}_{3 \mathrm{G}}$ (Gadhi), $\mathrm{D}_{4 \mathrm{~L}}$ (Lekhagaon), and $\mathrm{D}_{5 \mathrm{~K}}$ (Kunathari) are dummy variables. Standard deviations of these variables from mean are no so far significant. The mean of above these variables represents properly household data collected from primary sources. 
Table 1: Mean and Standard Deviations: Semi Log Regression Model

\begin{tabular}{lc}
\hline Variables & Mean (Standard Deviation) \\
\hline Income lost $\left(\ln \mathrm{Y}_{\text {TIL }}\right)$ & $4.94(5.25)$ \\
Agriculture labor $\left(\mathrm{X}_{\text {lagl }}\right)$ & $1.96(1.47)$ \\
Agricultural income $\left(\ln \mathrm{X}_{\text {agli }}\right)$ & $4.32(5.4)$ \\
Early warning $\left(\mathrm{D}_{1 \mathrm{lew}}\right)$ & $0.06(.25)$ \\
Knowledge of ${ }^{\text {Disaster }}$ & $0.52(.51)$ \\
$\left(\mathrm{D}_{2 \mathrm{kd}}\right)$ & $0.13(.341)$ \\
$\mathrm{D}_{3 \mathrm{G}}($ Gadhi) & $0.22(.42)$ \\
$\mathrm{D}_{4 \mathrm{~L}}$ (Lekhagaon) & $0.63(.48)$ \\
$\mathrm{D}_{5 \mathrm{~K}}($ Kunathari) & \\
\hline
\end{tabular}

The sample households of Sotkhola water basin and its catchment areas (Gadhi, Lekhagaon and Kunathari) have 4.94 means of income loss contributed majorly by agricultural income and agriculture labor. Only about 50 percent households have knowledge about disaster and disaster management but least has knowledge about early warning system. In addition, three catchment areas have heterogeneity.

\section{Socio Economic Variables Influencing Household Vulnerability}

Table 2 provides the results of semi log regression model of dependent variable, income loss of household $\left(\ln \mathrm{Y}_{\mathrm{TIL}}\right)$ is dependent variable and the proportion of agricultural labor $\left(\mathrm{X}_{\text {lagl }}\right)$, type of house $\left(\mathrm{X}_{2 \mathrm{th}}\right)$, the proportion of agricultural income $\left(\ln \mathrm{X}_{\text {agli }}\right), \mathrm{D}_{\text {lew }}$ (early warning), $\mathrm{D}_{2 \mathrm{kd}}$ (knowledge of disaster), $\mathrm{D}_{3 \mathrm{G}}(\mathrm{Gadhi}), \mathrm{D}_{4 \mathrm{~L}}$ (Lekhagaon), and $\mathrm{D}_{5 \mathrm{~K}}$ (Kunathari). There are ten parameters: $\beta, \beta_{1^{\prime}}, \beta_{2^{\prime}} \beta_{3^{\prime}}, \beta_{4^{\prime}} \beta_{5^{\prime}} \beta_{6}$ and $\beta_{7^{\prime}}$.

Table 2: Results of Semi Log Regression Model: Dependent Variable is Income Loss

\begin{tabular}{llll}
\hline Regressors & Coefficient & Std. Error & $\begin{array}{l}\text { P value } \\
\text { (significance) }\end{array}$ \\
\hline Constant & 32.41 & 4.87 & 0.00 \\
Ln Aglabor $\left(\mathrm{X}_{1}\right)$ & -5.24 & 1.58 & 0.007 \\
LnTotal Income $\left(\mathrm{X}_{2}\right)$ & 0.37 & 0.28 & 0.206 \\
Lnagincome $\left(\mathrm{X}_{3}\right)$ & 0.44 & 0.32 & 0.204 \\
$\mathrm{D}_{1}$ Knowledge of disaster $\left.(\mathrm{kd})\right)$ & -5.43 & 1.43 & 0.003 \\
(yes=1, $0=$ others) & 11.07 & 3.91 & 0.016 \\
$\mathrm{D}_{2}$ (Early warning $)($ yes $=1,0=$ others) & -13.65 & 3.70 & 0.004 \\
$\mathrm{D}_{3}($ Gadhi) $)($ yes $=1,0=$ others $)$ & -21.81 & 4.53 & 0.001 \\
$\mathrm{D}_{4}$ Lekhagaon $)(\mathrm{yes}=1,0=$ others) & & \\
$\mathrm{R}^{2}=0.78 ; \mathrm{Df}=(8,11) ; \mathrm{F}$ value $=5.024 ; \mathrm{N}=642$ & & \\
\hline
\end{tabular}




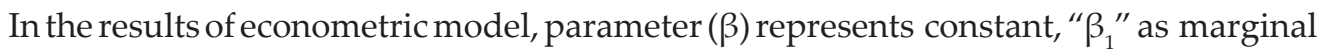
change of agriculture labor, " $\beta_{2}$ " as marginal change of type of house, " $\beta_{3}$ " for the proportion of agricultural income, " $\beta_{4}$ " as marginal change of early warning, " $\beta_{5}$ " as marginal change of knowledge of disaster, " $\beta_{6}$ " as marginal change of Gadhi, " $\beta_{7}$ " as marginal change of Lekhagaon (as alternative of marginal change of Kunathari).

\section{DISCUSSION AND CONCLUSION}

Above result of semi log econometric model provides sufficient and necessary evidence on coefficient of independent variables on household vulnerability (income loss of household). Estimation of coefficient explains how much the change of household vulnerability is affected by the change of adaptive capacity, geography and climatic shock (the flood). In the result of the model, $\mathrm{R}^{2}$ value is 0.78 . It means approximately 78 percent variation of vulnerability (household income loss) explained by above independent variables. In another words, it indicates higher goodness of fit to the data. There is still 3.71 percent error term which includes the different unobserved variables. It indicates higher goodness to fit. $\mathrm{F}_{\text {cal }(8,11)}$ is 5.02 . It is compared with

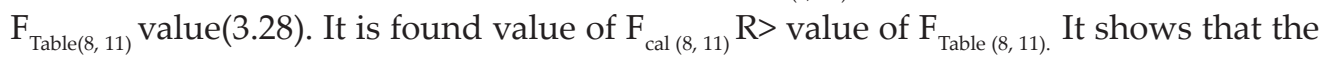
difference in variance between and within variety is significant at 5 percent. Further, there is no difference between sample means. Similarly, $\mathrm{P}_{\text {value }}$ is calculated 0.008 at 5 percent significance level. It shows no reasonable reason to reject no difference between sample means.

Ln total income loss (vulnerability) $=32.41-5.24 \mathrm{Ln}$ (ag labor) +0.376Ln (total income) +0.44 lnag income - 5.43 knowledge of disaster +11.07 early warning -13.65 Gadhi -21.187 Lekhagaon

Let us suppose that there are three factors: socio economic status and development, adaptation capacity and geographical factors. In the evidence of Sot Khola watershed areas, there was natural hazard happened in 2014 that is called flood. In that situation, there was available socio economic status contributing vulnerability of household and showing adaptive activity in different VDCs (Gadhi, Lekhagaon and Kunathari).

Household vulnerability is a threat to be controlled to household for peace, happy and normal livelihood. Above independent variables have either positive or negative relationships with household vulnerability in those three VDCs: Gadhi, Lekhagaon, and Kunathari. Let us present one by one independent variable influencing household vulnerability. 
- Household lose income in disaster, when agricultural income occurs. Therefore, agricultural income has impact (0.44) on household vulnerability. Let us assume that other variable remain constant, the loss proportion in total household income will increase by 44 percent when the proportion of agricultural income increases by 1 percent. It shows that agriculture is sensitive to the impact of flood and landslide.

- When we talk about total household income. It has also impact (0.37) on household vulnerability in terms of income loss. When 1 unit of total income increase, household vulnerability will increase by 37 percent. Therefore, the sources of total income of household are more sensitive to the impact of natural hazard.

- Early warning system reduces household vulnerability through preparedness and alertness. How much time earlier so much household will have time to move at safe place. In case of occurrence of early warning system, early warning system has not directly linked with household income loss. Therefore, early warning system has increased the cost of preparedness to reduce household vulnerability by 11 percent.

- The knowledge of disaster through either traditional method or experience or training will reduce household vulnerability because such knowledge provides skill to reduce the negative impact of natural hazard. In case of the occurrence of knowledge of disaster, household will reduce household vulnerability by 543 percent if other variables are remaining constant. Therefore, the knowledge of disaster has negative relationship with household vulnerability.

- Agricultural labor has the inverse relationship with household vulnerability. This hypothesis is rejected by the model. Agricultural labor has not been mobilized or has not capacity to move property or asset at the safe place. Therefore, agricultural labor has no effect on household vulnerability.

- There are three study areas such as Gadhi, Lekhagaon and Kunathari having household vulnerability. These areas have different household vulnerability. In above socio economic conditions, household vulnerability between Gadhi, and Lekhagaon are -13.65 percent and -21.18 percent respectively. It indicates different household vulnerability due to geographical factors. In Gadhi and Lekhagaon, household will have more resistance or resilient than Kunathari in case of disaster.

The result of above question from the model clearly indicates the dependency of vulnerability on agricultural income, total income and type of membership. Agricultural labor and knowledge of disaster have negative relationship with household vulnerability. Geography of Gadhi and Lekhagaon has resistance but Kunathari has no 
resistance. Therefore, resilience socio economic characteristic, adaptive preparedness and resilient geography are urgently needed for future.

\section{References}

Adger, W. N. (2000). Social and ecological resilience: Are they related? Progress in Human Geography, 24, 347-364.

Adger, W.N., Brooks, N., Bentham, G., Agnew, M., \& Eriksen, S. (2004). New indicators of vulnerability and adaptive capacity. London: Tyndall Centre for Climate Research.

Adger, W. N (2006). Vulnerability. Global Environmental Change, 16, 268-281.

Birkmann, J. (2007). Risk and vulnerability indicators at different scales: Applicability, usefulness and policy implications, EnvironmentalHazards,7(1), 20-31.

Blaikie, P., Cannon, T., Davis, I., \& Wisner, B.(1994). At risk: Natural hazards, people's vulnerabilities and disasters. (1st ed.), London: Rutledge.

Bolin, R. \& Stanford, L.(1998). The Northridge earthquake: Vulnerability and disaster. London: Rutledge.

Brooks, N. (2003). Vulnerability, risk and adaptation: A conceptual framework. Norwich: Tyndall Centre for Climate Research.

Cardona, O. D. (2003). The need for rethinking the concepts of vulnerability and risk from a holistic perspective: A necessary review and criticism for effective risk management. In G. Bankoff, G. Frerks \& D. Hilhorst (Eds.), Mapping vulnerability: Disasters, development and people (pp.37-51).London: Earthscan Publishers.

Central Bureau of Statistics (CBS).(1991). Population census. Kathmandu:CBS

-------. (2011). Population census. Kathmandu: CBS

Chambers, R. (1989). Vulnerability, coping and policy. IDSBulletin, 20(2),1-7.

Clark, W.C., Cash, D., Corell, R., Dickson, N., Hall, J.M., \& Parson, E. (2000). Assessing vulnerability to global environmental risks. Unpublished manuscript

DDC (District Development Committee) (2015). District Profile. Surkhet: DDC

Hoddinott, J.,\& Quismbing, A. (2003). Methods for microeconometric risk and vulnerability assessments. (Social Protection Discussion Paper Series No. 324).Washington, DC: Social Protection Unit, Human Development Network, The World Bank. 
IEDRO .2010). Bangladesh named country most vulnerable to natural disasters, the report. Bangladesh: IEDRO .Accessed from http://iedro.org/articles/ bangladesh-named-country-most-vulnerable-to-natural-disasters/

IPCC. (2012).Managing the risks of extreme events and disasters to advance climate change adaptation. Cambridge: IPCC

Ministry of Home. (2017). Nepal disasters report 2017: Road to Sendai. Kathmandu: Ministry of Home

Shen, Y., Zhu, Z., Li, L., Lv, Q., Wang, X.\& Wang, Y. (2011). Analysis of household vulnerability and adaptation behaviors to Typhoon Saomai, Zhejiang Province, China. Thailand: EEPSEA

TurnerII, B.L., Kasperson, R.E., Matson, P.A.,McCarthy,J.J., Corell, R. W., Christensen,L., Eckley, N., ...,\& Schiller, A. (2003). A framework for vulnerability analysis in sustainability science. PNAS (1st ed.) Publication in 2002 retrieved from http:// www.pnas.org/content/100/14/8074.full.pdf+html

Twigg, J. (2004). Disaster risk reduction: Mitigation and preparedness in development and emergency programming, Good practice review 9. Humanitarian practice network $(H P N)$. London: ODI

UNDP. (2004). Reducing disaster risk a challenge for development. Global report. New York: UNDP Bureau for Crisis Prevention and Recovery.

UNEP. (2004). Fresh water in Europe-facts, figures and maps. Châtelaine, UNEP/ DEWA Europe.

UNISDR. (2009b).UNISDRterminology on disaster risk reduction. Geneva: United Nations International Strategy for Disaster reduction (UNISDR).

Warmington, V. (1995). Disaster reduction: A review of disaster prevention, mitigation and preparedness. Ottowa: Reconstruction and Rehabilitation Fund of the Canadian Council for International Cooperation.

Watts, M. J. ,\& Bohle, H. G. (1993). The space of vulnerability: The causal structure of hunger and famine. Progress in Human Geography, 17(1), 43-67.

World Bank. (2016). The press release. Marrakesh: World Bank. http://www.worldbank. org/en/news/press-release/2016/11/14/natural-disasters-force-26-illionpeople-into-poverty-and-cost-520bn-in-losses-every-year-new-world-bankanalysis-finds 